\title{
THE IMPACT OF THE EUROPEAN UNION ACCESSION PROCESS ON THE PROLIFERATION OF GOOD GOVERNANCE PRACTICES IN TURKEY
}

Murat ÇETIN*

\begin{abstract}
Replacing the classic factors of production, knowledge, in other words "mental creativity", constitutes the real source of the wealth in today's world. The mankind is the source of this creativity is highly esteemed as the holiest body. In this new period following the industrial era, the nation-state concept has gone beyond the borders; and the new dynamics of globalization have emerged, which would be shared through the same values and organizational forms by all the people as a whole. In this new and "people-oriented" world system, "good governance" constitutes the new mode of rule. In this study, contributions of the European Union accession process which is an important motivation for progress in Turkey for realization of the good governance principles shall be discussed.
\end{abstract}

Keywords: Good governance, European Union, good governance in Turkey.

\section{TÜRKIYY'DE IYYİ YÖNETISŞIM UYGULAMALARININ GENIŞLEMESİNDE AVRUPA BİRLİĞI'NE KATILIM SÜRECİNIN ETKİSI}

\section{Özet}

Küreselleşme ile değişen dünya düzeninde klasik yönetim anlayışından iyi yönetişime geçiş sürecinde; Türkiye'nin bir yanda değişen dünya düzenine ayak uydurma çabaları diğer yanda tam üyesi olmak istediği Avrupa Birliği standartlarına erişebilme gerekliliği neticesinde hem ekonomik hem de toplumsal sorunları çözmek zorundadır. Yasal düzenlemeleri değiştirmek tek başına yeterli değildir, toplumsal yapının da değişikliklere uyum göstererek gelişmesi gerekir. Tabanda temel haklar ve insan haklarının korunması, demokrasi, sürdürülebilir kalkınma kavramlarının içeriği tam olarak hayata geçirildikten sonra şeffaflık, bilgi edinme, hesap verebilirlik unsurlarını tam olarak ihtiva eden iyi yönetişim anlayışını toplumun tüm katmanlarında sağlamak gerekir. Bu çalışmada; iyi yönetişim anlayışının gerekliliği çerçevesinde, Türkiye'nin Avrupa Birliği’ne katılım sürecinde ülkede iyi yönetişimi gerçekleştirmek adına yapılan düzenlemeler, bu düzenlemelerin uygulanabilirliği tartışılmaktadır.

Anahtar Sözcükler: İyi yönetişim, Avrupa Birliği, Türkiye’de İyi Yönetişim.

\footnotetext{
*Assistant Professor, Istanbul University, Faculty of Economics, Department of Economic Policy. E-mail: mcetin@istanbul.edu.tr
} 


\section{Introduction}

The most important contribution of globalization was probably the fact that even the person in the remotest part of the world can be aware of everything happening all over the world. This development did not only show each citizen of the world "how" the citizens of "the most developed" countries live but also "how they need to be governed" to reach high standards of living. It was naturally inevitable that this consciousness caused the citizens to question their own governments and ask for a government "that would provide the highest standards of living".

Therefore, an important consequence of the globalization given impetus by the developments in the knowledge and communication technologies, in this frame, has been the questioning of the quality of the provided public services and the new demands from the public. Apart from inspecting to what extent the public authority makes efficient use of the "scarce resources", it is concomitant that the consumer who is treated like a king in the "Knowledge Era" asks for "the best quality at the cheapest price" also from the public sector. Furthermore, it is a necessity of the time that within the scope of relation between state and citizen, service providers and receivers come side by side as "those paying the taxes, inspecting the expenditures, and being accountable and transparent.

Therefore, reflection of the Knowledge Era on the public sector is to provide service to the citizens by treating them like "customers or benefactors". This fact consequently made it necessary to increase the quality of the public services, to ensure efficiency, and to establish a transparent and controllable structure. When the governments started to ask themselves "How can we provide better quality, more efficient and effective services in our fields of activity?" this revealed the quality management models, and on this route "Good Governance" has been the most significant concept.

In this frame, the European Union brought its own understanding of governance through a document entitled "European Governance: White Paper". The document deals with how the Union uses the authority granted to it by its citizens. 
The enlargement process experienced within the European Union necessitated harmonization among all the applied policies to put into effect the idea of "Union"; and the existence of states with the ability to provide services at higher degrees of efficiency. Therefore, Turkey has an obligation to carry out comprehensive reforms in the public management throughout the EU accession process. This obligation requires Turkey, a country deprived of internal dynamics, to get help from EU principles and regulations during the "development" period, and this paves the way for "good governance".

There is no doubt that the principal reason for the change experienced in Turkey is the European Union (EU) accession process that started with the candidate status granted at the European Council Summit held in Helsinki in 1999. Turkey carried out extensive reforms in many fields as well as in the public management in order to comply with the criteria for joining the European Union and harmonize with the EU norms. When the content of public management reform is evaluated, it is seen that transparency, accountability and participation, which are the main elements of good governance, are emphasized.

Considering the fact that even the existence of the fundamental notions such as democracy, human rights and freedom are being questioned in Turkey in 2013, to what extent Turkey needs the European Union process and the good governance principles to be adopted in harmonization with this process is evident.

\section{Good Governance and Its Principles}

Throughout the history, associated with the progress of mankind, a number of improvements and changes has been experienced in the field of good governance as well as in all the other fields; notions such as "governance, governing, being governed" has been ascribed different meanings in different periods; and some new concepts such as traditional governance, flexible governance and modern governance have been produced.

Governance is the coordinated use of the resources by the means of planning, organization, orientation and inspection processes in order to attain specific objectives (Palabıyı, 2004, p.65). 
The government performing its function as an element of oppression, getting isolated from the people by embodying all the power has brought about some problems (Oktay, Pekküçüksen, 2004, p.10).

The fact that new world order has been getting more people-oriented and individual choices have been gaining more importance in the decisionmaking process has showed its effects on the mode of rule. A single person, group or organization having a say and imposing its own arrangements to the whole of the society could not hold out against the changing conjuncture.

The concept of governance was coined by the World Bank, and then it was used in some of the OECD reports while it is widely acknowledged that the term of good governance was first used at the United Nations (UN) Second Conference on the Least Developed Countries that was held in 1990. On the other hand, the meaning of these notions has been defined in a UNDP document. In that document, good governance has been defined as a combination of a number of elements among which participation, transparency and accountability are particularly emphasized. As a whole, these principles are mentioned as transparency, accountability, participation, responsiveness, rule of law, efficiency, equity and strategic vision (Turkish Ministry of Finance, 2003).

The governance has three fundamental aspects; these are economic, political and administrative governance. Economic governance involves the process of making decisions that affect the economic activities of the country and its relationships with the external economies; and has some impacts on equity, poverty and life quality. Political governance involves the decision-making process in order to constitute a strategy. As for the administrative governance, it describes the system through which the policies are enforced. When these three elements are considered together, good governance defines the structures and processes that govern the political and socioeconomic relationship (Ministry of Finance, Department of European Union and Foreign Affairs, 2003, p.1).

The World Bank, in its report entitled "Governance: The World Bank's Experience" of 1994, distinguishes "good" governance from "bad" governance by the following definition: "Good governance can be summarized as predictability, transparency and open mind in policy 
making; bureaucracy with a professional perception giving priority to the public benefit; the rule of law, transparent process and a strong civil society participating in the public life. On the other hand, the distinguishing characteristics of the "bad governance" are arbitrariness in policy making, a bureaucracy that is not held accountable, non-functioning and unfair judicial system, the misuse of the executive power, civil society isolated from the public life and widespread corruption (TUSIAD, 2002, p.176).

Although public administrations exist in order to facilitate the life, they have been gradually transformed into structures that make it more difficult. This fossilized structure prevented the governance concept to reach its aim by interpreting it arbitrarily; and resulted in the emergence of "good governance and bad governance" terms in the literature.

The principles of good governance show notable similarities to general governance literature. These can be summarized as multiparty democracy, respect for human rights and the rule of law, efficient public management, market economy and fighting against the poverty. Good governance, in a way, is a new form developed to compensate some deficiencies in the New Understanding of Public Management, and it is rearranged in a way to be appropriate to the developing countries. It is observed that the facilities required for efficient performance of the public management do not exist in those countries, and given that a well-functioning market economy and democratic administration are needed for the New Mode of Public Management, some new items have been added to the principles of the New Mode of Public Management; in this sense, good governance and the New Mode of Public Management are two connected strategies.

Governance is regarded as an outcome of the co-management concept based on the cooperation among the public sector, private sector and voluntary institutions, and that moves away from the narrow vision focusing on marketising the public services. In this regard, good governance refers to a management concept defending the human rights, preventing the decision makers from taking arbitrary decisions and informing the public opinion about the decisions made by the administration. Good governance requires the administration to ensure the participation of the people to the decisionmaking stage. Good governance is considered as one of the main elements for an effective government (Saygılıoğlu and Arı, 2003, p.130). 
In order to understand whether the governance is internalized or not in a society, it is necessary to check to what extent the nongovernmental factors are effective in the decision-making process.

The principles of good governance are briefly as follows:

Transparency: The main reason for a need to change the understanding of the governance is governor's being closed to questioning and not explaining the reason why they are taking some actions by hiding behind some excuses (Kuzey, 2003, p.12).

Accountability: This principle involves that decision makers, when questioned about the use of their authority, are supposed to give answers, to reformulate their decisions in face of the critics, and to accept their responsibility in case of improper decisions or practices (Samsun, 2003, pp.18-31).

Participation: This principle refers to participation of all the citizens, directly or by the means of intermediary institutions, to the decisionmaking process (Özer, 2006, p.80).

Responsiveness: This principle refers to the awareness of the citizens on the fact that they will be listened by the actors taking part in the public administration and that they will have suitable answers to their questions.

The Rule of Law: This principle means that the institutions act within the scope of the fairly formed legal framework, and people accept that laws will be enforced to their behaviour (Çukurçayır and Sipahi, p.54).

Equity: The concept of equity can be defined as the fair and impartial treatment of the similar events of daily life in terms of their social and legal natures

Strategic Vision: This concept explains the existence of a long-term, global vision based on social, cultural and historical fundamentals concerning human development and good governance for the people and the leaders (Çukurçayır and Sipahi, p.56). 


\section{Good Governance in the European Union}

The effective government envisaged by the governance model in the globalization process is a model in which the government undertakes production of the public goods and services for the internal and external security issues, and leaves the market to its own working mechanism (Erdem, 1996, p.4). Besides these mentioned relationships, globalization connects the governments to multi-supranational structures (Altan, 2011, p.101).

Governance as a new way to deal with the problems can be applied at different spatial scales: Global, National and Local. Global governance presupposes that all the states need to embrace the common problems related to the mankind in order to solve these problems. Particularly starting from the late twentieth century, nation states have been confronted with some general problems too general to be solved by their own internal mechanisms and concerning all the humanity. National governance is founded on the principle of separation of powers, and it enables the representation of all fractions of the society having different opinions and interests, and can be defined as the political and managerial system that makes decisions by taking into consideration the opinions of the citizens, and attempts to implement these decisions by the means of an effective, efficient, transparent and accountable public management. In the frame of the national governance, the role granted to the government is rather to direct the provision of the service than to produce these services (Bıçk1 and Sobac1, 2011, p.11).

Globalization is a source of some arrangements related to the governance at the universal level. The Universal Declaration of Human Rights, the International Covenant on Civil and Political Rights and UN Millennium Declaration are some of the foremost examples about it.

Globalization process has given birth to another supranational structure: the European Union.

Three fundamental reasons can be mentioned for the governance emerging as an element of oppression within the European Union. First element is the requirement for a work in depth concerning the EU policies after the 
enlargement process. Second point is the serious crisis of legitimacy that is being experienced by the EU. Finally, it is observed that the division of the policies affects the transparency and the clarity of these policies negatively. The governance model of the EU lies on the principles of deregulation, flexibility and pertinence (Scohout and Jordan, 2005, pp.204-208). The citizens are required to be able to reach the decision-makers and to be effective in the decision-making process in order to participate actively in the administration. It is not possible to claim the existence of such a condition in the states with a centralized structure. At the local level the citizens may be in perpetual contact with the decision-makers and they can have some direct influences on the decision-making process as well as participating in the process by the intermediary of the civil organizations.

\subsection{Sigma}

The existence of important differences among the administrative systems of the member states in the Union constitutes an important threat for the administrative and political functioning of the EU.

Particularly after the enlargement, it is required to ensure the political processes working efficiently and the convergence of the member state's institutional system level.

SIGMA is a joint initiative of the EU and the OECD that in brief provides technical support in the public area for constituting and applying reform programs in the EU candidate countries.

SIGMA, in its paper published in November 1999 and entitled "European Principles for Public Management" (OECD, SIGMA, 1999) has attempted to determine the fundamental principles required for the candidate countries to conform their administrative systems to the administrative systems existing in the EU member states (Fournier, 1998, p.121). It contains the homework to be fulfilled by all the candidate countries wishing to join the European Union. The administrative dimension is constituted by the concept of "administrative capacity". The principles of good governance related to administrative law can fulfil the requirements of this concept.

The aims of the SIGMA program can be listed as follows (Sustainable Institutions For European Union Membership, 1998, p.22): 
- to assist beneficiary countries in their search for good governance to improve administrative efficiency and to promote adherence of public sector staff to democratic values, ethics and respect of the rule of law;

- to provide support to build up indigenous capacities at the central government level to face the challenges of internationalization and of European Union integration plans; and

- to support initiatives of the European Union and other donors to assist beneficiary countries in public management reform and to contribute to the coordination of donor activities.

\subsection{White Paper on European Governance}

Within the EU, a number of fundamental principles have been accepted and some instruments have been developed during the development period of the strategies and concepts of "such as "good governance", "better/successful regulations", "sustainable development". In this framework, the principles of subsidiarity and proportionality determine the fundamental approach of the EU concerning doing regulations or not. Green Paper and White Paper establishing the bases of a comprehensive consultation procedure, guides concerning the way in which successful regulations should be prepared, the SLIM program (simplification of the legislation for creating internal market), analyses of business world, budget and ecology effects constitute the main instruments developed by the EU (Aykın, 2010, p.6).

Governance as a matter of fact in the European Union has been analyzed by the European Commission in the light of the document entitled White Paper on European Governance prepared in 2002 (Kesim and Petek, 2005, p.42). According to the White Paper, good governance has five basic characteristics. These characteristics are expressed as openness, participation, accountability, effectiveness and coherence (Commission of the European Communities, 2001). Furthermore, White Paper points out some changes for realizing good governance. These are more comprehensive changes and practices in the union policies, improving the quality in applying EU policies and strengthening the relations between the European governance and the other regions of the world. The idea that some alternative ways should be tried because classic methods could not 
solve the existing problems and participation should be increased as it is recognized by the Commission has arisen. To put the accountability into complete effect, the working and responsibility fields as well as the job definitions of the institutions should be clarified.

\subsection{Ombudsman}

Ombudsman was first created in Sweden in 1713, and then took place in the Swedish Constitution gaining the quality of a constitutional establishment in 1809. The ombudsman establishment in the light of the Swedish model became very widespread all around the world after 1950's (Fendoğlu, 2010, p.10). European ombudsman that was created in consequence of a large consensus, and also supported strongly among the EU institutions member states has been considered as a step for fulfilling the gap between European Union and European Union citizens and for making more accountable and responsible establishments from EU institutions (Song and Vincent, 2008, p.481).

\subsection{Regulations Made in the EU on Good Governance}

European Convention on Human Rights (ECHR):

The freedom of expression was incorporated in the Article No. 10 of the Convention. Freedom of expression is at the heart of the good governance. In antidemocratic administrative structures where freedom of expression does not exist, the search of good governance is not in question. Therefore, firstly human rights need to be guaranteed for good governance.

Charter of Fundamental Rights of the European Union:

The Article No. 41 of the Charter is entitled "Right to Good Administration". This right includes the right of every person to be heard, before any individual measure which would affect him or her adversely is taken; the right of every person to have access to his or her file, while respecting the legitimate interests of confidentiality and of professional and business secrecy; the obligation of the administration to give reasons for its decisions (Charter of Fundamental Rights to European Union, Art.41, p.18). 
In spite of the fact that all European Union member states are parties to the European Convention on Human Rights, the elaboration of EU Charter on Fundamental Rights, proves the importance given by the European Union to human rights. The points that do not take place in the European Convention on Human Rights have been added to the Charter of Fundamental Rights of the European Union and in such a way that legal gaps have been avoided in protecting human rights.

Code of Good Administrative Behaviour:

The Code of Good Administrative Behaviour has been accepted on September 6, 2001 by the European Parliament. With these rules, it is determined what can be the expectations of the citizens from the administration and what principles shall be respected by the public staff while fulfilling their function (The European Ombudsman, 2005, pp. 6-7).

Committee of Ministers of the Council of Europe:

The decision No. 31 of September 28, 1977 (77) regulates individual protection before the public administration's procedures.

Recommendation on Access to Official Documents:

In the first article of the related decision, official documents are defined as "All information recorded in any form drawn up or received and held by public authorities and linked to any public or administrative function, with the exception of the functions" (Recommendation 2 of the Committee of Ministers to Member States on Access to Official Documents, 2002). It is known that these decisions of the Committee of Ministers are taken into consideration for the EU accession process of Turkey, and that these decisions constitute the preamble for the General Administrative Procedure Law draft and have considerable influence on the Right to Information Act.

\section{Good Governance Practices in Turkey in the EU Accession Process}

The new public management approach was brought to agenda in Turkey in 2000 through a meeting entitled "Good governance on the way to the EU" carried out jointly by TUSIAD, OECD, Ministry of Foreign Affairs and the European Union. The concept of governance was articulated for 
the first time in 2001 through the programme of the state minister in charge of the economy, Kemal Derviş, "Programme for Transition to a Strong Economy" in 2001, and then appeared as the name of the State reform of the 58th Government of Turkey in the Urgent Activity Plan (Güler, 2003, p.7).

The national programme of 2003 draws in detail the frame of the administrative reform in Turkey as well as what Turkey shall do in the EU harmonization process. The headlines of the administrative reform are as follows (EU Ministry, 2013):

- Financial Control

- Transition to strategic planning in the ministries and public agencies

- "Performance-based budget" in the Public Finance Management

- Extension of the budget's scope and Financial Transparency

- Strengthening State Economic Enterprise's Governance

- Strengthening governance in the public sector

- Basic Law of Public Management

- Institutional review

- State personnel regime reform

- Local Administration's Reform

- Regional Development Agencies

- Citizen's Right to Information

- E-Turkey project

- Defining ethic rules in the public sector

- Rationalizing public investment programme 
The mode of rule focusing on the citizen or close to the citizen is one of the most important quality indicators in providing public services (Grunow, 1994, p. 374). Turkish public management fell short of following the rapid change experienced all around the world through 1990's. Bureaucratic structure underlies the experienced economic problems and many social troubles and the administration's insufficiency to keep up with the global affairs can be mentioned as well. Being clear that many of the problems are not ready to be solved with the existing structure, restructuring in the public management proves to be unavoidable. In this way, both the society's trust in the state will be increased and a more efficient and effective use of the public resources will be ensured (Bilgin, 2007).

The ground for the reforms being in process in Turkey's public management is "The New Public Management" approach.

\subsection{The Regulations Made in Turkey on Good Governance}

Law No. 3071 on the Use of the Right to Petition:

Concerning the Law No. 3071 on the Use of the Right to Petition, as a result of the amendment carried out on 02.01.2003, the law has been paralleled with the constitution.

Law No. 4982 on the Right to Information:

According to its first article, the purpose of this law is to regulate the rules and principles for the right to information according to the principles of equality, impartiality and openness that are the necessities of a democratic and transparent government.

Public Financial Management and Control Law No. 5018:

According to the Article No. 7 of this law, in order to ensure supervision in the acquisition and utilization of all types of public resources, the public shall be informed in time.

Municipality Law No. 5393: 
With the Municipality Law No. 5393, the strategic planning obligation was imposed on special provincial administrations. In its application in Turkey, according to the Article No. 76 of the Municipality Law No. 5393, the City Councils are comprised of representatives of public professional organizations, trade unions, civil society organizations, political parties, public entities, universities.

Law No. 5197 on Special Provincial Administration:

When the Special Provincial Administration Law No. 5197 of 24/06/2004 aiming to restructure the special provincial administrations was brought before the Turkish parliament, the law's preamble was as follows "In the light of the global approach of the EU at which we are in accession process with and the European Charter on Local Self-Government, the special provincial administrations are stipulated to be reliable, clear and transparent, obliged to be accountable, able to provide efficient, effective and good quality services" (Law No. 5302 on Special Provincial Administration, 2005).

Law No. 3628 on Declaration of Property and Fighting against Bribery and Corruption:

This law requires certain public officials to declare their personal properties in order to struggle against corruption and bribery.

Local Agenda 21 and City Councils:

City Councils developed in Turkey during the Local Agenda 21 process and stipulated in the Article No. 76 of the Municipality Law No. 5393 seems to be an ideal structure (Republic of Turkey Official Gazette, 2001).

Development Agencies:

Regional development agencies have been implemented in order to speed up the regional development and to diminish the interregional and intraregional differences.

E-government Practices: 
E-government practices enable the information to be more accessible, and make contributions to diminishing bureaucracy fees.

\section{Ombudsman:}

The first step carried out in this field has been the Law No. 5227 on Basic Principles and Restructuring of Public Management. In the Article No. 42 of the law, it is stipulated to elect an ombudsman in every city local administrations and affiliated institutions and the unions to help the resolution of the conflicts arising from the procedures and actions related to legal and real person.

Afterwards, the Ombudsman Institution has been founded by the means of the Law No. 5548 on Ombudsman Institution. Ombudsman Institution, "upon any complaints on the functioning of the administration, within the frame of the characteristics of the Republic of Turkey mentioned in the constitution, is responsible for analyzing, investigating all kinds of procedures and behaviours of the administration through the sense of justice, in terms of respect for human rights, conformity to the rule of law and equity, and to make recommendations to the administration" (Law on Ombudsman, art. 9).

With these regulations, the Ombudsman Institution considered by the European Union commission as very instrumental for the accountability and transparency in the actions and procedures and for increasing the effectiveness of the public management has been put into effect.

The other regulations can be listed as follows:

The Decree on the Rules and Principles of Application and Ethical Principles of Behaviour of the Public Staff coming into effect by its publication in the Official Gazette on 13.04.2005:

In the Article No. 19 of the Decree, it is stipulated that the civil servants shall help the people use their right to information, shall provide the requested information and documents in conformity with the procedure in case of a request from a legal or natural person, submit to the public attention within the bounds of the law and the authorization of their top managers, the bidding process, the performance and audit reports. 
Law No. 5227 on Basic Principles and Restructuring of the Public Management:

In the first article of the law, it is implied that the foundation of an accountable, participative, transparent public management system that is based on human rights and freedoms is aimed.

Provincial and District Human Right Boards:

Provincial and district human right boards have been founded by the Regulation on the Establishment, Duties and Operations of the Provincial and District Human Right Boards published at the Official Gazette No. 25298 of November 23, 2003. By the means of the new regulations, the supervision of the administrative tutelage of the central administration on the local administrations has been restricted, and in this way it is desired to endow local administrations with stronger, more democratic and participatory structures.

\subsection{Good Governance in the Development Plans}

In the years following 1960 when a new era started for Turkey, the economic and social development was stipulated to be realized under the initiative and leadership of the government through five-year plans. An important place and function were granted to the government in the fulfilment of the objectives determined in the plans, within this frame some recommendations were brought for an improvement in the human resources and organization structure and the simplification of the procedures for a better and more efficient work of the public management (Administration Development Department, 1994, p.71). The mode of reform in the development plans could not follow a linear trend and it showed some changes depending on the developments in the world. For example, in the first three plans, the goals such as "it will be ensured to have the public management fulfilling its duties in a more efficient way" was amended as "the function of the public management would be reconsidered and redefined" starting from the fourth plan, and attention was called that center should concentrate on a few and critical functions. Through the eighth and ninth plans planning the 2000's, new recommendations were made in parallel with the New Public Management approach and some evaluations concerning the 
reasons why the initial targets could not be attained took also place in those plans in detail. The approach of the ninth plan is a reflection of the approach showed about the initiative of reform launched with the Law on Basic Principles and Restructuring of the Public Management. From this point of view, the plan has the feature of a text through which all the works envisaged to be done on the basis of this law are presented (Canpolat and Kesik, 2011, p.73).

In the ninth plan, nearly in all fields, emphasis was done on the concept of governance, and the requirement for European Union harmonization process was mentioned in the Articles 3, 7, 276, 285, 289. This proves that European Union is a reference for Turkey's straightforward restructurings.

In the Article No. 285; it is mentioned that "The Preliminary National Development Plan (PNDP) for 2004-2006 was prepared within the scope of the EU accession process in order to determine the medium-term main priority areas to be financially supported in the field of economic and social harmonization. Within the scope of this plan, which stipulates improving and expanding local development initiatives, strategic operational regional development programs with independent budgets and cross border cooperation programs were put into practice 12 NUTS Level 2 regions determined by taking into account the socioeconomic development index."

In the Article No. 687; emphasis was put on the fact that the public management transformation would continue on the basis of good governance: "The public management system will be restructured in the framework good governance approach. Laws on the establishment of public agencies and organizations will be revised in a way to prevent duty and authority conflicts. In order for all public institutions and organizations to be able to perform their principal duties, consistency of their duties and responsibilities with organization structures will be ensured." It has been also stated that e-government practices would increase the good governance in the public management.

\subsection{Good Governance in Turkey in the Regular Progress Reports}

Progress report is a detailed document about the steps taken or not taken by the EU candidate and potentially candidate countries on the yearly 
basis; what they could realize or not in terms of harmonization with the Copenhagen criteria; how they could realize those they could not realize (Economic Development Foundation IKV, 2013).

The European Commission prepares a report for every candidate country within the accession process to assess the progress made by that country within the preparation process (European Union Ministry, 2013). The first regular progress report for Turkey was published in 1998; that was followed by the regular yearly reports.

In the first regular progress report published in 1998 for Turkey; it was stated that in reason of the excess of public expenditures and biased disparity of these expenses, expenditures destined to good investments are restricted, in the field of public management, emphasis was put on the need for a higher degree of investment; even in the first report it is noticed that there are some indicators showing that reform was required in the public management and public expenditures. In the regular progress report published in 2000; by mentioning that "In order to support and safeguard macroeconomic stabilization, the government's stabilization programme relies on an ambitious list of structural reforms to be implemented on the next three years. The reform agenda covers practically all key areas: public finances, public management, the privatization of state enterprises, the banking and the agricultural sector and the social security system etc" (European Union Ministry, 2013), it was pronounced clearly for the first time that the reforms should start. In the 2003 regular progress report, for the first time emphasis was put on the governance concept and that efforts for putting the governance concept into practice were started and that independent institutions would contribute to good governance in connection with their functions.

Meanwhile, 2012 Turkey Progress Report, the most recently published one, contains some conclusions on governance, as well as on the other fields with a good number of "but":

"Limited progress in terms ofdelegation of authority to local administrations, in the Ombudsman Law, the ombudsman does not have the right to conduct inquiries on its own initiative and excludes the military acts of the Turkish Armed Forces, the law as it stands does not set out any decision-making 
process of the Ombudsman Institution; all line ministries and major public agencies prepared performance programmes and accountability reports. However, such planning activities need to be better coordinated; four years after the adoption of the Public Financial Management Law some components are still missing, in particular measures to enhance the accountability, efficiency and transparency of the budgeting process..."

Even if the 2012 Progress Report is considered in Turkey as rigid by a major part of the society, progress reports are actually nothing else than the presentation to the candidate country of the assessment prepared after monitoring closely for one year the same candidate country. That's the reason why progress reports are of a great importance for Turkey, which is a candidate country, and they constitute a base for the reforms that are done or shall be done.

In the Regular Progress Report of 2014, it was indicated that the transparency and accountability those are the most important factors of a good governance, needed improvement in a number of areas. Regular progress reports has a great importance for Turkey as a candidate country as well as are essential for plans which has been made or are going to be made.

\subsection{Current Level Attained by Turkey in terms of Good Governance Practices}

It should be accepted that Turkey has made a considerable progress in the process of full membership to the EU in a way that it has the longest EU membership procedure. Croatia started its membership negotiation on the same day as Turkey and it will be a member of the EU on July 1, 2013 as the 28th member country.

Given that negotiating candidate countries became a member of the EU approximately in 7 years, Turkey has guaranteed the longest period of membership negotiations as it completed only one paragraph in 8 years.

Having started negotiations on October 3, 2005, Turkey could complete the Chapter on Science and Research which covers just a few pages of the EU acquis of 120 thousand pages. Turkey started negotiations for 13 Chapters in total. 
In addition, Turkey holds the record for being the candidate country about which the highest number of progress reports is written.

This situation can be questioned for both sides. The European Union, as a regional organization, based its criteria on the international documents acknowledged at the global level. The European Union sets standards in all fields for the member states and expects the member and candidate states to comply with these standards. From the beginning of the formation of the union, it was worded that the union aims for a world with supremacy of democracy, respect for human rights and freedom. The reason for all these statements is the idea of the European Union to create "European" individuals. Before being a member of the union, solving these problems will make the integration to European Union process easier.

In the EU accession process, especially in the last 10 years, there have been significant reforms and adjustments in Turkey. However, it is understood from the chapters not opened for negotiation and extension of the accession period that these regulations are not sufficient. For instance; although EU member states did not put any blocks, three titles were not opened with an excuse not to hinder the competitive power. "Public procurement" and "social policies and employment" are the examples of chapters which have not been opened yet. The fact that Turkey hasn't opened these chapters for negotiation with an aim not to lose its competitive power has got the following meaning: "Turkey does not intend an economic structure which competes in the international platform."

EU has brought some rules which prevent the illegal restriction of the competition to provide a healthy running mechanism of market economy through competition policy.

EU has introduced general principles for public procurement such as transparency, equal treatment, free competition and non-discrimination.

With the Chapter on Social Policy and Employment, EU basically aims to increase employment, to improve working and living conditions, and to develop human resources for a sustainable employment structure.

As most of these reforms have not been realized yet, Turkey ranks the 38th among 59 countries in 2012 Annual World Competitiveness Yearbook, and 
it ranked 59th among 142 countries in 2011-2012 Global Competitiveness Report of World Economic Forum.

Public Procurement Law which has been changed by the parliament 19 times in the last 9 years has eliminated the transparency and paved the way for corruption.

In Turkey, the most notable obstacle to the transparency which is the biggest weapon of the developed countries to minimise the government is the fact that the Court of Accounts reports prepared for the auditory outcomes of the public agencies on defence, security and intelligence will not be declared to the public.

As a matter of fact, Turkey ranks the 54th in the Global Corruption Report of the Transparency International in 2012. (BBC, 2012) In order to be able to mention about the good governance, we need to accept that the first condition is transparency. However, it seems that Turkey is getting further from transparency day by day.

In Turkey, the general opinion on both the public administrations and the bureaucrats authorized in the administration is negative; and this creates lack of confidence in the government. The reason for this negative attitude is the failure of giving explanations for the acts and operations, and that even if they give an explanation, it is obscure. However, in order to be able to mention the term of governance, the notions such as transparency, clarity, accountability must be internalized.

The fact that negotiations for the Chapter on Social Policy and Employment has not been opened yet primarily means that approximately 1,100 people a year and four people a day die in work accidents. Moreover, Turkey has taken its place in the "black list" of International Labour Organisation.

We have seen above the results of Turkey's intend to bring into action the concept of good governance actually in care of government. We can list the other results of unwillingness that comes out of by arguing against the reforms which must be accomplished in the process of European Union. For example, to continue with field of economy;

While Turkey has a GDP of 740 billion dollars, a per capita income of 10 billion 400 dollars, the portion of its GDP in the world trade is 1.29 per 
cent. As a result of this, Turkey is the 17 th most competitive economy in terms of its market size.

Turkey ranks the 133rd in terms of labour market effectiveness and the 25 th in the world with 541 patent applications.

Turkey ranks the 71st among 184 countries in 2012 in the "Doing Business" report of the World Bank.

In 2012, Turkey shared the 61st rank with Cuba and Latvia in the transparency list ordering 183 countries in terms of corruption and fraud and attracting considerable attention of the foreign investors.

With respect to the OECD's report in 2013, Turkey is among the countries which have the most unfair distribution of income.

In terms of democracy and freedom, bad governance has led to the results as follows:

Turkey ranks the 77th among 96 countries in the 2012 Rule of Law Index of the "World Justice Project" in terms of the protection of fundamental rights including the right to life.

Turkey ranks the 77th among 146 countries in terms of Gender Inequality Index.

Turkey ranks the 92nd in 2012 in terms of Human Development Index.

Turkey ranks the 138th among 178 countries in the "World Press Freedom Index" published by the Reporters without Borders".

Turkey ranks the 2nd with its compensation penalties amounted to 23 million 424 thousand 794 Euro that European Court of Human Right adjudged for the European Countries in 2012. In addition, Turkey overtly violates the law by not obeying 1,241 decisions of the European Court of Human Rights.

Turkey ranks the 89th with Nicaragua in 2010 research on "Democracy Index" including 167 countries in the World in terms of democracy, human rights and freedom of thought and takes place in the group of hybrid regime (partially free) countries such as Tanzania and Uganda. 
The importance that EU attaches to the fundamental rights and freedoms and human rights can be seen in every aspect of the union. The former Czech President Vaclav Havel emphasized divinity of the human in his motto: "humans are more important than the boundaries". This importance lies behind the emergence of good governance. As a candidate country, if there is not absolute freedom, it is not possible to mention transparency and accountability with reference to good governance.

In this sense, local administrations stand as the most important structure to provide the required setting for the application of good governance. However, it is difficult to say that the understanding of local administration in Turkey has been shaped around good governance. Due to the understanding of prevalent central administration, the financing of local administrations is provided by central administrations to a large extent. That's why in Turkey "occupygezi" movement arouse a big interest and notice at a surprisingly large scale at the beginning of June in 2013.

To stand against global competition, Turkey must make urgent reforms for both financial issues (tax payment regularization, labour market regularization, struggling with unregistered economy etc.) and democratic issues.

EU process has a vital importance in providing institutionalization for a stable economy and democracy. The biggest support will be from EU for Turkey which will require strengthening of democracy on the basis of a new constitution, extending democratic legitimacy principle to all public administrations and restructuring local administrations.

After November 2000 and February 2001 crisis which were the biggest ones that Turkey has experienced in its history, the road map to handle the crisis, "Turkey's Programme for Transition to a Strong Economy", under the leadership of Kemal Derviş worded good governance as follows: "it is aimed to provide transparency and accountability in the process of allocating resources in the public, to irrevocably prevent the irrational interference and to empower good governance and to fight against corruption" (TCMB,2013). Subsequent to it, it was mentioned as the name of state reform in the 58th Government's Immediate Action Plan (Güler, 2003, p.7). 
On April 17, 2007, Turkey announced that it would have realized the "Programme for Alignment with the EU Acquis" including 188 legal regulations and 576 secondary regulations by 2013. According to that alignment programme, it was supposed that 114 laws in 2007-2008, 30 laws in 2008-2009, and 64 laws in 2009-2013 would be put into effect. In his dissertation entitled "AKP and the European Union - Turkey Relationships", Silvyo Güzelbahar determined how many laws were put into effect by the AKP by 2012. Accordingly, in the annual activity reports of the European Union Harmonization Committee, it is seen that 14 laws were enforced in 2008-2009, 8 laws in 2008-2009, 7 laws in 2009-2010 and only 1 law in 2010-2011 (Baştürk, 2012).These figures contradict with the determined attitude of Turkey in the process of full membership to the EU starting from its application to the European Community on July 31, 1959.

US-based Freedom House which makes researches on democracy, freedom and human rights, showed Turkey among "partly free" countries in its 2014 report. Many African countries with poor human rights records are among "partly free" countries like Turkey. These countries include Burkina Faso, Burundi, Morocco, Kenya, Liberia, Libya, Egypt, Niger, Nigeria, Tanzania, Tunisia, Uganda and Zambia. Moreover, it was pointed out in the report "It's time to fully freeze the accession process of Turkey and keep them out of Europe permanently. People dream for a democratic future for the country must change their ideas about what must be done on the path. (Taraf, 2014). The European Union has evolved from a economic partnership to a political union, in which the protection of fundamental rights and freedoms are not visible until 1987, thought since then the importance given to human rights and freedoms have been felt in all areas of Union. This importance rests on the basis of the emergence of good governance concept. In a country where there isn't freedom in the strict sense, it isn't possible to talk about transparency and accountability, thereby good governance. Moreover, according to Freedom of the Press 2015, report. Several countries including Turkey have experienced serious deterioration over the past five years on freedom of speech. Turkey has fallen by 11 points on a 100-point scale since 2010 (Freedom of the Press, 2015). 


\section{Conclusion}

Good governance explains a governance approach which ensures participation of people to the decision-making process, information of people about the decisions taken by the government, and prevents arbitrary decisions by the decision-makers and promotes human rights.

In addition to the arbitrary governance of the administration, Turkey has a bad record in terms of human rights and freedom, statist mentality, cumbersome bureaucracy, a non-working legal system which shows itself in the punishment decisions in European Court of Human Rights in the applications of democracy.

From an economic perspective, in spite of overcoming 2008 financial crisis with the least loss and being the 17th biggest economy all over the world, Turkey could not succeed in running all market economy with all institutions and rules and also it could not carry its economy to a competitive structure intending to use scarce resources in an effective way.

To talk about the education, Turkey seems to be stuck in the middle income trap and although it seems possible to establish an economic structure which allows overcoming this reality with creation of high value-added productions by a "creative" population the rote learning and repressive mindset in the education system prevents this creativity. This reality can be seen in the PISA education research of OECD in which Turkey has a very low rank in all branches.

It seems that for Turkey overcoming its underdeveloped circle in both economic and democratic platforms will only be possible thanks to the European Union which is an external dynamic.

Longer-term impacts of the reforms that Turkey has realized in the European Union process can be observed in every field of daily life. Henceforth, it is only possible for good governance practices to adopt a revolutionist and transformative nature and thereby to make contribution to the economic and political development of Turkey with the European Union. 


\section{References}

Akgeyik, T. (2004). Kamu Yönetiminde Reform Arayışları: İKY Perspektifli Bir Yaklaşım, Hukuk ve Adalet Eleştirel Hukuk Dergisi, 1(2), İstanbul.

Akıllıoğlu, T. (1981). Bireyin Yönetsel İşlemler Karşısında Korunması ve Yönetim Hukukumuz, Amme İdaresi Dergisi, 14(3), s. 54.

Aktan,C. (2008). Demokrasi ve İyi Yönetişim, http://www.yerelsiyaset.com/pdf/ mart2008/2.pdf

Alkan, H. (2000). "Karar Alma Süreçlerine Katılım Sistemleri Açısından Türkiye Ekonomik ve Sosyal Konseyi”, Ankara: TODAíE Dergisi, 33(2), s.58

Altan, M. (2011). Küresel Vicdan, İstanbul: Timaş Yayınları.

Aşkın, M. D. (2003). “Eşitlik ve İyi Yönetişim”, İyi Yönetişimin Temel Unsurları, Ankara: T.C. Maliye Bakanlığı Avrupa Birliği ve Dış İlişkiler Dairesi Başkanlığı Yayını.

Baştürk, D. (24.08.2012). AB Yolunda Yarım Arpa Boyu, Taraf.

Bıçkı, D. \& Sobacı, M. Z. (2011) Yerel Yönetimden Yerel Yönetişime: Post-Fordizm Bağlamında Yerel Yönetimleri Anlamak, Yönetim Bilimleri Dergisi, 9, s.11.

Bilgiç, V. \& Göksu, T. (2004). "Yeni Gelişmeler Işı̆̆ında Türkiye’de Kamu Yönetimi ve Yerelleşme Eğilimleri”, 2004 Türkiye İktisat Kongresi Tebliğ Sunuşları.

Bilgin, M. H. (2007) Kamu Yönetiminde Yeniden Yapılanma Tartışmaları, Perşembe Konferansları, Ankara.

Börzel, T. (2010) European Governance: Negotiation and Competition in the Shadow of Hierarchy, JCMS.

Canatan, Bilal (2001) Düşünce Tarihinde Kamu Hukukunda Avrupa Birligi'nde Yerellik İlkesi, Ankara: Galeri Kültür Yayıncılık, 2001.

Commission of the European Communities (2001), "European Governance: A White Paper", Brussels: COM.

Çukurçayır, M.A. (2003) “Çok Boyutlu Bir Kavram Olarak Yönetişim”, Çağdaş Kamu Yönetimi 1, Ed: M. Acar, H. Özgür, Ankara: Nobel Yayınları, p.271.

Çukurçayır M. A. \& Sipahi, E. "Yönetişim Yaklaşımı ve Kamu Yönetiminde Kalite”, Sayıştay Dergisi, Ankara,50-51, p.54.

Dokuzuncu Kalkınma Planı (2006), T.C Resmi Gazete, 26215, 1 Temmuz 2006.

Dreschler, W. (2005) "The Rise and Demise of the New Public Management," Postautistic Economics Review, 33, p.27.

Emrealp, S. (2005) Yerel Gündem 21 Uygulamalarına Yönelik Kolaylaştırıcı Bilgiler El Kitabı, İstanbul: Birmat Matbaası. 
Erdem,Y. (1996) “ Küreselleşen Ne?”, İktisat Dergisi, 362, p.4

Eryılmaz, B. (2008) Bürokrasi ve Siyaset, Bürokratik Devletten Etkin Yönetime, İstanbul:Alfa Yayınları.

Eryılmaz, B. (2008) Kamu Yönetimi, Ankara: Okutman Yayıncılık.

Fendioğlu, H. T. (2010) Kamu Denetçiliği (Ombudsmanlık), Ankara: Stratejik Düşünce Enstitüsü.

Fournier, J. (1998) "Governance and European Integration, Reliable Public Administration", Preparing Public Administrations for the European Administrative Space, OECD, p.121.

Grunow, D. (1994) "Kommunale Leistungsverwaltung: Bürgernaehe und Effizienz”, Kommunal Politik, (Hrsg. R. Roth, H. Wollmann), Leske+Budrich, Opladen, p.374.

Güler, B. A. (2003) “Devlette Reform”, Kamu Yönetimi Dünyası, Ankara: TMMOB Mimarlar Odas1, 4(13).

Güler, B. A. (2006) Yerel Yönetimler, Liberal Açıklamalara Eleştirel Yaklaşım, Ankara: İmge Kitabevi.

Günday, M. (2003) İdare Hukuku, Ankara: İmaj Yayıncılık.

Gündoğan, E. (2004): "Yönetim Reformlarının Gerekliliği Bağlamında İyi Yönetişim ve Türkiye Uygulanabilirliğii”, Sivil Toplum, p.6.

Güzelsarı, S. (2003) "Neo-liberal Politikalar ve Yönetişim Modeli”, Amme İdaresi Dergisi, 36(2), p.20

Harrison, G. (2005) The World Bank, Governance And Theories Of Political Action In Africa British Journal Of Politics And International Relations, 7(2), pp. 240-260.

Hope, K. R. (2009) 'Capacity development for good governance in developing societies: lessons from the field', Development in Practice, 19(1), p.79.

http:/www.abgs.gov.tr/files/AB_Iliskileri/AdaylikSureci/IlerlemeRaporlari/

http://www.abgs.gov.tr/files/KAPB/muzakere_surecinde_mevcut_durum_web_tr.pdf http://www.avrupa.info.tr/tr/ab-ve-tuerkiye/katilim-muezakereleri/ilerleme-raporlari. html

http://www.bbc.co.uk

http://europa.eu/legislation_summaries/justice_freedom_security/combating _ discrimination/133501_en.htm

http://www.ikv.org.tr/images/upload/data/files/degerlendirmenotuilerlemenin matematigi.pdf 
www.oecd./org/puma

http://www.taraf.com.tr/haber/turkiye-nin-ozgurluk-notu-dustu.htm (17.01.2013)

İGB (İdareyi Geliştirme Başkanlığı), 21. Yüzyıla Girerken Türkiye'de Kamu Yönetiminin Geliştirilmesi ve Bazı Ülkelerdeki Uygulamalar - Araştırma Raporları II, Ankara: İGB.

Junaid A., Shantayan D., Stuti K., Shekhar S., (2005) "Decentralization and Service Delivery”, World Bank Research Policy Paper, 1(3603), p.4.

Karabulut, T. (2007) “Türkiye’de Bölgesel Kalkınma Politikaları ve Kurumsal Gelişmelerle İlgili Genel Bir Değerlendirme", Yerel Yönetimler Üzerine Güncel Yazılar II Uygulama, Ankara: Nobel Yayınları.

Koçel, T. (2010) İşletme Yöneticiliği, 12. Basım, İstanbul: Beta Yayınları.

Kooiman, J. (2003) Governing as Governance, London: SAGE.

Keleş, R. (1992) “Belediyeciliğimizde Son Gelişmeler”, Çağdaş Yerel Yönetimler, 1(2), p.13.

Keleş, R. (1995) “Hizmette Halka Yakınlık (Subsidiarity) İlkesi ve Yerel Yönetimler”, Çă̆daş Yerel Yönetimler, 4(1), pp.5-7.

Kent Konseyi Yönetmeliği (2006), T.C Resmi Gazete, 26313,08 Ekim 2006.

Kesim, H. K. \& Petek, A. (2005) “Avrupa Komisyonu’nca Belirlenen İyi Yönetişimin İlkeleri Çerçevesinde Türk Kamu Yönetimi Reformunun Bir Eleştirisi”, Ankara: TODAİE Dergisi, 38(4), p.42.

Kılıç, K. \& Urhan, Y. (2012) Şeffaf ve Hesap Verebilir Kamu Yönetimi Sempozyumu http://www.tbmm.gov.tr/yayinlar/kamu_yonetimi_sempozyumu.pdf

Kuzey, P. (2003): "Şeffaflık ve İyi Yönetişim”, İyi Yönetişimin Temel Unsurları, Ankara:T.C. Maliye Bakanlığı Avrupa Birliği ve Dış İlişkiler Dairesi Başkanlığı Yayını.

Leftwich, A. (1994) "Governence, The State and The Politicis of Development", Development and Change, 25, pp. 371-372.

Lindberg, L. N. \& Scheingold, S. (1970) Europeans Would be Polity. New Jersey: Prentice Hall Inc. Englewood Cliffs, p.129.

Marks, G. (2000) "European Integration from the 1980s: State Centric v. Multilevel Governance", Journal of Common Market Studies, 34(3), Alınt1 yapan Clive Archer, The European Union: Structure and Process, London, Continuum, 2000, p.33

Maliye Bakanlığı (2003) UNDP Governance for Sustainable Human Development (A UNDP Policy Paper), İyi Yönetişimin Temel Unsurları, Ankara: Ayrıntı Basımevi.

Mccormick, J. (1996) The European Union: Politics and Policies, Oxford, Westview Press. 
Mehter Aykın, S. (2010) “Türkiye’nin Avrupa Birliği’ne Sürdürülebilir Katılımı İçin Düzenleyici Etki Analizinin Gerekliliği’, Yönetim ve Ekonomi, Manisa: Celal Bayar Üniversitesi İ.İ.B.F., 17(2), p.6.

Mosse, D. (2005) 'Global governance and the ethnography of international aid', in D. Mosse and D. Lewis, eds. The Aid Effect: Giving and Governing in International Development, London: Pluto Press.

Mutta, S. (2005) İdarenin Denetlenmesi ve Ombudsman Sistemi, İstanbul: Kazanc1 Kitap.

Nohutçu A. \& Balcı A. (2008) "Kamu Yönetiminin Yeni Perspektif ve Dinamizmi: 'Kamu'nun Yönetilmesinden 'Kamu'nun Yönetmesi Anlayışına Doğru”, Kamu Yönetiminde Çağdaş Yaklaşımlar, 2. Baskı, Ankara: Seçkin Yayıncılık.

Official Journal of the European Communities (2000) "Charter of Fundamental Rights of the European Union" 41(1), p.18

Oktay, E. \& Pekküçüksen Ş. (2004) “Küreselleşen Dünyada Sivil Toplum Odaklı Yönetim, Roller Beklentiler ve İyi Yönetişimin Unsurları”, Çanakkale: I. Ulusal Sivil Toplum Kuruluşları Kongresi.

Özdemir Tsarouhas, U. (2010) “AB Perspektifinden Yerel Yönetişim: İlkeler, Beklentiler ve Tecrübeler”, Yerel Kalkınmanın Yönetişimi, İstanbul: Atak Matbaa, p.20.

Özdemir, U. E. (2003) “Stratejik Planlama ve İyi Yönetişim”, İyi Yönetişimin Temel Unsurları, Ankara: T.C. Maliye Bakanlığı Avrupa Birliği ve Dış İlişkiler Dairesi Başkanlığı Yayını, p.125.

Özer, M. A. (2006) “Yönetişim Üzerine Notlar”, Sayıştay Dergisi, 63, p.80.

Palabıyık, H. (2004) "Yönetimden Yönetişime Geçiş ve Ötesi Üzerine Açıklamalar”, Amme İdaresi Dergisi, 37(1), p.65.

Polat, N. (2003) "Saydamlık, Hesap Verme Sorumluluğu ve Denetimin Etkinliği”, Sayıştay Dergisi, 49, p.71.

Pivoras, S. and Visockyt, E. Public Governance Concepts and their Use in Civil Service Reform Research. Viesoji politika ir administravimas, 1, pp.27-40.

Rhodes, R. (1996) “The New Governance: Governing without Government”, Political Studies, 44, pp.652-667.

Rosamond, B. (2007) European Integration and the Social Science of EU Studies: The Disciplinary Politics of a Subfield International Affairs 83(1), pp:231-252

Samsun, N. (2003) "Hesap Verebilirlik ve İyi Yönetişim”, İyi Yönetişimin Temel Unsurları, Ankara: T.C. Maliye Bakanlığı Avrupa Birliği ve Dış İlişkiler Dairesi Başkanlığı Yayını, pp.18-31. 
Savunma, Güvenlik ve İstihbarat İle İlgili Kamu İdarelerine Ait Devlet Mallarının Denetimi Sonucunda Hazırlanan Raporların Kamuoyuna Duyurulmasına İlişkin Yönetmelik (2012), T.C Resmi Gazete, 25385, 15 Ağustos 2012

Saygılığlu, N. \& Arı S. (2003) Etkin Devlet, Kurumsal Bir Tasarı ve Politika Önerisi, İstanbul: Sabancı Üniversitesi.

Schout, A. and Jordan, A. (2005) “Coordinated European Governance: Self Organized or Centrally Steered?”, Public Administration, 83(1), p.204.

Sustainable Institutions For European Union Membership (1998), Sigma Papers No:26.

Song, W. and Vincent D. S. (2008) "Euroceptics and Europhiles in accord: the creation of the European Ombudsman as an institutional isomorphism”, Policy and Politics, 36(4), p.481.

Soylu, H. (2003) “Etkinlik ve İyi Yönetişim”, İyi Yönetişimin Temel Unsurları, Ankara: T.C. Maliye Bakanlığı Avrupa Birliği ve Dış İlişkiler Dairesi Başkanlığı Yayını, p.78.

Sweden, L. (1987) Series A No: 116 (26.03.1987); Gaskin v. UK, Series A No. 160.

The European Ombudsman, 2005.

Türkiye’nin Güçlü Ekonomiye Geçiş Programı, http://www.tcmb.gov.tr/yeni/duyuru/ eko_program/program.pdf

TÜSİAD(2002) Kamu Reformu Araştırması, İstanbul: TÜSİAD.

United Nations Convention Against Corruption (2003), UNGA Res. 58/4.

United Nations Convention Against Corruption (2003), UNGA Res. 58/4.

United Nations Millennium Declaration (2000) Resolution Adopted by the General Assembly (A/55/L.2), 8th Plenary Meeting.

Varki, H. (2008) Yerel Yönetişimin Türkiye'de Uygulanabilirliği: Konya Örneği, Yayımlanmamış Yüksek Lisans Tezi.

Verheijen, A.J.G. (2000), "Administrative Capacity Development: A Race Against Time?" WRR Scientific Council for Government Policy, Working Document, The Hague, 107, p.18.

3628 Sayılı Mal Bildiriminde Bulunulması, Rüşvet Ve Yolsuzluklarla Mücadele Kanunu (1990), T.C Resmi Gazete, 20508, 4 May1s 1990.

5018 Sayılı Kanun İle Yönetişim İlke Ve Esasları Çerçevesinde Kamu Hizmetlerinin Sunumu (2001), T.C. Resmi Gazete, 24295, 22 Ocak 2000.

5302 Sayılı İl Özel İdaresi Kanunu (2005), T.C Resmi Gazete, 25745, 04 Mart 2005. 